Vol III. No.2, Maret 2019, hlm. 117 - 124

Available online at www.jurnal.una.ac.id/indeks/jmp

\title{
PENGARUH MODEL PEMBELAJARAN ADVANCE ORGANIZER BERBASIS PETA KONSEP TERHADAP HASIL BELAJAR MAHASISWA MATEMATIKA
}

\author{
Nurdalilah ${ }^{*}$, Haryati Ahda Nst $^{2}$ \\ Pendidikan Matematika, FKIP Universitas Muslim Nusantara Al-Washliyah, \\ Medan Sumatera Utara \\ e-mail : "1 nurdalilah1989@gmail.com, \\ ${ }^{2}$ haryatiahda@yahoo.co.id
}

\begin{abstract}
Abstrak
Tujuan penelitian ini adalah untuk mengetahui apakah terdapat pengaruh model pembelajaran advance organizer berbasis peta konsep terhadap hasil belajar mahasiswa matematika pada mata kuliah struktur aljabar. Penelitian ini merupakan suatu penelitian eksperimen semu dengan desain penelitian pretest posttest control group design. Variabel dalam penelitian ini terdiri dari dua jenis yaitu variabel bebas dan variabel terikat. Pada penelitian ini yang menjadi variabel bebas adalah model pembelajaran advance organizer dan pembelajaran konvensional sedangkan variabel terikat dalam penelitian ini adalah hasil belajar hasil belajar mahasiswa matematika pada mata kuliah struktur aljabar. Populasi penelitian ini adalah seluruh mahasiswa matematika semester V UMN AlWashliyah Medan. Sampel penelitian kelas V-C (kelas kontrol) dan kelas V-D (kelas eksperimen). Instrumen yang digunakan adalah tes, selanjutnya data dianalisis dengan uji t. Berdasarkan analisis data, hasil belajar mahasiswa matematika pada mata kuliah struktur aljabar dengan menerapkan model pembelajaran advance organizer pada siswa lebih tinggi dibandingkan dengan hasil belajar mahasiswa matematika pada mata kuliah struktur aljabar dengan menerapakan pembelajaran konvensional.
\end{abstract}

Kata Kunci: Hasil Belajar Mahasiswa Matematika, Advance Organizer.

\begin{abstract}
The purpose of this study was to determine whether there was an influence of advance organizer learning models on the learning outcomes of mathematics students. This research is a quasi-experimental study with a pretest posttest control group design. The variables in this study consist of two types, namely the independent variable and the dependent variable. In this study, the independent variable is the advance organizer and conventional learning learning model, while the dependent variable in this study is the learning outcomes of mathematics student learning outcomes in the subject of algebraic structure. The population of this study was all the fifth semester mathematics students of UMN Al-Washliyah Medan. The research sample was V-C class (control class) and V-D class (experimental class). The instrument used is a test, then the data is analyzed by $\mathrm{t}$ test. Based on data analysis, mathematics student learning outcomes on the subject of algebraic structures by applying advanced organizer learning models to students is higher than the learning outcomes of mathematics students in the algebraic structure courses by applying conventional learning.
\end{abstract}

Keywords : Mathematics Student Learning Results, Advanced Organizer 
Vol III. No.2, Maret 2019, hlm. 117 - 124

Available online at www.jurnal.una.ac.id/indeks/jmp

\section{PENDAHULUAN}

Mata kuliah struktur aljabar merupakan salah satu mata kuliah yang ada di Jurusan Pendidikan Matematika UMN Al-Washliyah Medan. Struktur aljabar adalah ilmu yang mempelajari suatu himpunan dengan satu atau lebih operasi biner yang diberlakukan pada sistem aljabar tersebut. Menurut Nurlaelah (2009:12) mata kuliah Struktur Aljabar merupakan suatu mata kuliah yang memuat konsep-konsep yang abstrak, sehingga mahasiswa seringkali mendapat kesulitan dalam mempelajarinya. Untuk mengatasi hal tersebut, seorang dosen harus mampu membantu dan mengarahkan mahasiswanya supaya dapat mempelajari materi-materi pada mata kuliah tersebut menjadi lebih menarik dan bermakna.

Peran dosen memang sangat penting dalam menentukan proses pembelajaran yang membuat mahasiswa tidak jenuh dan bosan dalam mengikuti perkuliahan. Proses pembelajaran akan terlaksana dengan baik jika tujuan pembelajaran tersebut persiapkan dengan matang. Tujuan pembelajaran dalam mata kuliah Struktur Aljabar adalah agar diharapkan mahasiswa memahami lebih dalam tentang struktur aljabar dan dapat menerapkannya dalam menyelesaikan masalah aljabar sederhana, serta mampu berpikir logis dan bernalar secara matematis dalam menyelesaikan suatu masalah.

Pembelajaran

yang

menyenangkan, tidak terlepas dari model pembelajaran yang diterapkan dalam pembelajaran tersebut. Dosen dapat memilih model yang tepat jika memiliki kompetensi yang sesuai dengan profesi yang disandangnya. Keterampilan membuka dan menutup pembelajaran adalah salah satu dari beberapa keterampilan dalam pembelajaran yang harus dimengerti dan diimplemetasikan. Pembukaan dalam pembelajaran merupakan awal dari proses dimulainya belajar mengajar mahasiswa dan dosen, jika dari proses awal mahasiswa sudah tidak tertarik dan merasa tidak senang dengan apa yang dilakukannya, maka hasil yang diperoleh juga tidak maksimal. Untuk mewujudkan tujuan tersebut sangat dibutuhkan peran serta dosen sebagai proses pengelola pembelajaran. Tujuan pembelajaran dan proses pembelajaran saling terkait, apabila keduanya berjalan selaras maka akan berakibat pada hasil belajar mahasiswa.

Hasil belajar adalah gambaran kemampuan mahasiswa dalam memenuhi suatu harapan pencapaian pengalaman belajar dalam satu kompetensi dasar. Hasil belajar tampak sebagai terjadinya perubahan tingkah laku pada diri mahasiswa, yang dapat diamati dan diukur dalam bentuk perubahan pengetahuan sikap dan keterampilan. Abdurrahman (2003:130) mengatakan bahwa hasil belajar adalah kemampuan yang diperoleh mahasiswa setelah melakukan suatu kegiatan belajar. Kemampuan yang diperoleh adalah hasil yang dicapai dalam bentuk angka-angka atau skor setelah diberikan tes hasil belajar setiap akhir pembelajaran.

Hasil belajar merupakan faktor penting dalam pendidikan sebagai perwujudan nilai yang diperolah mahasiswa melalui proses 
Vol III. No.2, Maret 2019, hlm. 117 - 124

Available online at www.jurnal.una.ac.id/indeks/jmp

pembelajaran. Dari sisi mahasiswa, hasil belajar merupakan tingkat perkembangan mental yang lebih baik bila dibandingkan pada saat sebelum belajar. Tingkat perkembangan mental tersebut terwujud pada jenis-jenis ranah kognitif, afektif, dan psikomotor. Sedangkan dari sisi guru/dosen, hasil belajar merupakan saat terselesainnya bahan pelajaran.

Untuk meningkatkan hasil belajar mahasiswa diperlukan inovasi model pembelajaran yang dapat mendorong mahasiswa lebih siap dan aktif dalam pembelajaran karena keberhasilan mahasiswa dalam belajar ditentukan oleh kualitas pembelajaran serta kesiapan mahasiswa itu sendiri untuk mengikuti proses pembelajaran. Oleh karena itu, mahasiswa haruslah mempunyai modal yang mantap yaitu pengetahuan dasar sebelum materi tersebut diajarkan untuk menguasai bahan pelajaran. Model pembelajaran yang dapat diterapkan antara lain pembelajaran kooperatif, model pembelajaran Advance Organizer dengan bantuan penggunaan peta konsep dan sebagainya.

David Ausubel

mengemukakan bahwa model pembelajaran Advance Organizer merupakan suatu cara belajar untuk memperoleh pengetahuan baru yang dikaitkan dengan pengetahuan yang telah ada pada pembelajaran, yang artinya setiap pengetahuan mempunyai struktur konsep tertentu yang membentuk kerangka dari sistem pemprosesan informasi yang dikembangkan dalam pengetahuan (ilmu) itu. Dalam membantu mahasiswa menanamkan pengetahuan baru dari suatu materi, sangat diperlukan konsep-konsep awal yang sudah dimiliki mahasiswa yang berkaitan dengan konsep yang akan dipelajari. Untuk mengetahui konsep-konsep yang telah dimiliki oleh mahasiswa dapat dilakukan dengan pertolongan peta konsep.

Adapun yang dimaksud dengan peta konsep adalah ilustrasi grafis konkret yang mengindikasikan bagaimana sebuah konsep tunggal dihubungkan ke konsep-konsep lain pada kategori yang sama. Sehingga peneliti tertarik untuk melakukan penelitian dengan judul konsep.

Sehingga peneliti tertarik untuk melakukan penelitian dengan judul "Pengaruh Model Pembelajaran Advance Organizer Berbasis Peta Konsep Terhadap Hasil Belajar Matematika Mahasiswa Pada Mata Kuliah Struktur Aljabar"

\section{METODE}

Penelitian ini merupakan penelitian eksperimen semu atau quasi experiment. Sugiyono (2011:12) menyatakan bahwa penelitian eksperimen adalah metode penelitian yang digunakan untuk mencari pengaruh perlakuan tertentu terhadap yang lain dalam kondisi yang terkendali. Variabel dalam penelitian ini terdiri dari dua jenis yaitu variabel bebas dan variabel terikat. Pada penelitian ini yang menjadi variabel bebas adalah model pembelajaran advance organizer dan pembelajaran konvensional sedang- 
Vol III. No.2, Maret 2019, hlm. 117 - 124

Available online at www.jurnal.una.ac.id/indeks/jmp

kan variabel terikat dalam penelitian ini adalah hasil belajar mahasiswa matematika mata kuliah struktur aljbar. Penelitian ini dilakukan di Universitas Muslim Nusantantara AlWashliyah Medan. Populasi penelitian ini adalah seluruh mahasiswa matematika semester $\mathrm{V}$ sedangkan sampel adalah mahasiswa semester V-C (kelas kontrol) dan mahasiswa semester V-D (kelas eksperimen).

Rancangan eksperimen yang digunakan dalam penelitian ini adalah pretest posttest kontrol group design. Dalam rancangan ini terdapat dua kelompok yang dipilih secara random yang dijadikan satu sebagai kelas eksperimen dan satu kelas sebagai kelas kontrol.

Adapun desain penelitian ini adalah sebagai berikut

\begin{tabular}{lccc}
\hline Kelompok & $\begin{array}{c}\text { Pretes } \\
t\end{array}$ & $\begin{array}{c}\text { Perlakua } \\
\mathrm{n}\end{array}$ & $\begin{array}{c}\text { Postes } \\
t\end{array}$ \\
\hline $\begin{array}{l}\text { Eksperime } \\
\text { n }\end{array}$ & $O_{1}$ & $X_{1}$ & $O_{2}$ \\
\hline Kontrol & $O_{1}$ & & $O_{2}$ \\
\hline Keterangan \\
$\mathrm{X} \quad \begin{array}{c}\text { = Diberi perlakuan } \\
\text { Advance Organizer }\end{array}$ \\
$\mathrm{O}_{1} \quad=$ Pretest \\
$\mathrm{O}_{2} \quad=$ Postest
\end{tabular}

Pada desain ini kelas eksperimen diberi perlakuan dengan model pembelajaran Advance Organizer dan kelas kontrol diberi perlakuan pembelajaran konvensional. Kedua kelas diberi pretest dan postest. Adapaun tujuan diberikan pretest untuk melihat kesetaraan subjek penelitian sedangkan postes diberikan untuk melihat hasil belajar mahasiswa matematika.
Teknik pengumpulan data dalam penelitian ini menggunakan tes. Riduwan (2006) mengatakan tes adalah serangkaian pertanyaan atau latihan yang dugunakan untuk mengukur keterampilan pengetahuan, intelegensi, kemam-puan atau bakat yang dimiliki individu atau kelompok. Prosedur pengumpulan data pada penelitian ini adalah menyiapkan perangkat tes hasil belajar.

Selanjutnya, diadakan pelaksanaan penelitian yang diawali dengan memberikan soal pretest dan dilanjutkan dengan pelaksanaan model pembelajaran advance organizer pada kelas eksperimen dan pembelajaran konvensional pada kelas kontrol, dan kemudian di beri soal postes setelah mendapat perlakuan. Perangkat pembelajaran yang dikembangkan adalah rencana pelaksanaan pembelajaran (RPP) dan lembar kerja. Untuk pengolahan data diawali dengan mendeskripsikan hasil belajar kognitif dengan menghitung rata-rata dan standar deviasi kemudian uji normalitas menggunakan uji KolmogrovSmirnov dengan bantuan SPSS 11 dan uji homogenitas menggunakan Uji Levene dengan bantuan SPSS 11. Pada akhir dilakukan uji t dengan bantuan SPSS 11 untuk menguji hipotesis kemudian ditarik kesimpulan.

\section{HASIL DAN PEMBAHASAN}

Pada tahap ini akan dideskripsikan hasil analisis data yaitu hasil belajar mahasiswa matematika yang meliputi deskripsi pretes dan postest. Selain itu akan 
Vol III. No.2, Maret 2019, hlm. 117 - 124

Available online at www.jurnal.una.ac.id/indeks/jmp

diuraikan juga mengenai hasil uji normalitas dan uji homogenitas serta uji t untuk data yang diperoleh.

Hasil pretes pada kelas eksperimen memperoleh rata-rata 11,82 dan standar deviasi 5,86 sedangkan pada kelas kontrol memperoleh rata-rata 11,61 dan standar deviasi 5,69. Kemudian hasil post tes pada kelas eksperimen memperoleh rata-rata 15,58 dan standar deviasi 5,27 sedangkan pada kelas kontrol memperoleh rata-rata 12,45 dan standar deviasi 5,29. Jadi, dapat disimpulkan bahwa rata-rata skor hasil belajar mahasiswa matematika pada kelas eksperimen lebih tinggi dari pada kelas kontrol.

Sebelum dilakukan analisis uji $\mathrm{t}$ hasil belajar mahasiswa matematika pada kelas eksperimen dan kontrol terlebih dahulu dilakukan uji prasyarat yakni uji normalitas dan uji homogenitas. Uji normalitas pada penelitian ini menggunakan Uji KolmogorovSmirnov sedangkan uji homogenitas menggunakan Homogenity of Variances (Levene Statistic).

\section{Tabel 1. Uji Normalitas}

\begin{tabular}{|c|c|c|c|c|}
\hline & \multirow[t]{2}{*}{ KELAS } & \multicolumn{3}{|c|}{$\begin{array}{l}\text { Kolmogorov- } \\
\text { Smirnov(a) }\end{array}$} \\
\hline & & $\begin{array}{l}\text { Sta } \\
\text { tisti }\end{array}$ & & \\
\hline & & c & Df & Sig. \\
\hline NIL & Kontrol & .14 & 33 & 101 \\
\hline \multirow[t]{2}{*}{$\mathrm{Al}$} & & 0 & & \\
\hline & Eksperimen & $\begin{array}{r}.13 \\
8\end{array}$ & 33 & .114 \\
\hline
\end{tabular}

Dari hasil Uji KolmogorovSmirnov (Sunyoto, Danang: 2013) untuk kelas eksperimen diperoleh hasil signifikansi 0,114 sedangkan pada kelas kontrol diperoleh hasil signifikansi $=0,101$ dengan hipotesis nilai significance (sig.) >
0,05 sehingga dapat disimpulkan bahwa data berdistribusi normal.

Tabel 2. Uji Homogenitas

\begin{tabular}{cccccc}
\hline $\begin{array}{l}\text { Levene } \\
\text { Statistic }\end{array}$ & df1 & & df2 & & Sig. \\
\hline .049 & & 1 & & 64 & .825 \\
\hline
\end{tabular}

Dari hasil Homogenity of Variances (Levene Statistic) di atas diperoleh hasil signifikansi $=0,825$ dengan hipotesis nilai significance (sig.) $>0,05$ yang berarti kedua kelompok memiliki varians yang sama sehingga kedua kelompok berdistibusi homogen. Setelah pengujian prasyarat analisis data di peroleh maka analisis yang digunakan selanjutnya adalah analisis parametrik dengan menggunakan uji t. 
Vol III. No.2, Maret 2019, hlm. 117 - 124

Available online at www.jurnal.una.ac.id/indeks/jmp

Tabel 3. Hasil Uji t Kemampuan Hasil Belajar Kognitif Siswa

Independent Samples Test

\begin{tabular}{|c|c|c|c|c|c|c|c|c|c|c|}
\hline & & $\begin{array}{l}\text { Leven } \\
\text { for Eq } \\
\text { Vari }\end{array}$ & $\begin{array}{l}\text { Test } \\
\text { lity of } \\
\text { ces }\end{array}$ & & & t-test for & Equality o & Means & & \\
\hline & & \multirow[b]{2}{*}{$F$} & \multirow[b]{2}{*}{ Sig. } & \multirow[b]{2}{*}{$\mathrm{t}$} & \multirow[b]{2}{*}{ Df } & \multirow{2}{*}{$\begin{array}{l}\text { Sig. }(2- \\
\text { tailed) }\end{array}$} & \multirow{2}{*}{$\begin{array}{c}\text { Mean } \\
\text { Differe } \\
\text { nce }\end{array}$} & \multirow{2}{*}{$\begin{array}{l}\text { Std. } \\
\text { Error } \\
\text { Differe } \\
\text { nce }\end{array}$} & \multicolumn{2}{|c|}{$\begin{array}{c}95 \% \\
\text { Confidence } \\
\text { Interval of the } \\
\text { Difference } \\
\end{array}$} \\
\hline & & & & & & & & & Lower & Upper \\
\hline \multirow[t]{2}{*}{$\begin{array}{l}\text { Hasil Belajar } \\
\text { Struktur } \\
\text { Aljabar }\end{array}$} & $\begin{array}{l}\text { Equal } \\
\text { variances } \\
\text { assumed }\end{array}$ & .049 & .825 & 2.694 & 64 & .009 & 3.3939 & $\begin{array}{r}1.2599 \\
7\end{array}$ & $\begin{array}{r}5.911 \\
02\end{array}$ & $\begin{array}{r}.8768 \\
6\end{array}$ \\
\hline & $\begin{array}{l}\text { Equal } \\
\text { variances } \\
\text { not } \\
\text { assumed }\end{array}$ & & & 2.694 & $\begin{array}{r}63.67 \\
4\end{array}$ & .009 & 3.3939 & $\begin{array}{r}1.2599 \\
7\end{array}$ & $\begin{array}{r}5.911 \\
27\end{array}$ & $\begin{array}{r}.8766 \\
1\end{array}$ \\
\hline
\end{tabular}

Berdasarkan Uji t diperoleh $\mathrm{t}_{\text {hitung }}=2,694>\mathrm{t}_{\text {tabel }}=2,03$ atau nilai signifikansi $0,000<0,05$ berarti $\mathrm{H}_{0}$ ditolak. Artinya model pembelajaran advance organizer berpengaruh positif terhadap hasil belajar mahasiswa matematika pada mata kuliah struktur aljabar dan lebih tinggi dari pada hasil belajar kognitif dengan menerapkan pembelajaran konvensional.

\section{PEMBAHASAN}

\section{Faktor Pembelajaran}

Model pembelajaran advance organizer ini didasari oleh teori pembelajaran kognitif yaitu teori pembelajaran yang fokus pada masalah atau pertanyaan yang berkaitan dengan kognisi atau pengetahuan. Menurut para ahli yang mendukung teori ini, belajar merupakan proses mental yaitu suatu pemrosesan informasi. Teori ini menjelaskan bahwa perilaku seseorang ditentukan oleh persepsi dan pemahamannya mengenai situasi yang berkaitan dengan tujuan belajar. Teori pembelajaran kognitif pada model pembelajaran advance organizer ini dikembangkan oleh Ausubel. Menurut Ausubel (dalam Joice, Weil \& Calhoun, 2008: 106), pembelajaran akan lebih efektif ketika dosen menggunakan penjelasan, peta konsep, demonstrasi, ilustrasi dan analogi-analogi yang sesuai.

Operasi mental tambahan yang terlibat dalam pencapaian konsep pada tingkat klasifikatori ialah mengadakan generalisasi bahwa dua contoh atau lebih sampai batas-batas tertentu itu ekuivalen. Dalam operasi mental ini mahasiswa berusaha untuk mengabstraksi kualitas-kualitas yang sama yang dimiliki oleh objek-objek itu. 4) tingkat formal, untuk pencapaian konsep pada tingkat formal, mahasiswa harus dapat menentukan atribut-atribut yang membatasi konsep. Kita dapat menyimpulkan bahwa mahasiswa telah mencapai suatu konsep pada tingkat formal, bila mahasiswa itu dapat memberi nama konsep itu, mendefinisikan konsep itu dalam bentuk atribut-atribut, men- 
Vol III. No.2, Maret 2019, hlm. 117 - 124

Available online at www.jurnal.una.ac.id/indeks/jmp

deskriminasi dan memberi nama atribut -atribut yang membatasi, dan mengevaluasi atau memberikan secara verbal contoh-contoh dan noncontoh dari konsep. Lebih jauh, Klausmeier menyarankan bahwa operasi-operasi yang terlibat dalam pencapaian formal dapat induktif ataupun deduktif.

Pernyataan berikutnya adalah pengetahuan akan diperoleh seseorang dengan proses penjelasan bukan dengan penemuan. Hal tersebut menegaskan bahwa pembelajaran yang menggunakan banyak aktivitas belajar dapat memberikan makna belajar bagi setiap mahasiswa. Pembelajaran yang memanfaatkan penjelasan dosen yang diiringi dengan kegiatan demonstrasi alat peraga dapat lebih efektif dalam menamkan makna konsep kepada mahasiswa. Hal ini dikarenakan siswa mengikuti banyak kegiatan dalam proses memahami konsep materi sehingga memunculkan makna. Oleh karena itu, dosen semestinya mengkombinasikan proses penyampaian materi pelajaran dengan beberapa pendekatan pembelajaran sehingga dapat memunculkan belajar yang bermakna.

\section{Hasil Belajar Mahasiswa Matematika}

Berdasarkan hasil skor pretes diperoleh data bahwa hasil nilai mahasiswa di kelas eksperimen dan kelas kontrol mempunyai hasil belajar yang tidak jauh berbeda secara signifikan. Hal ini terlihat dari hasil analisis pretest kedua kelas tersebut. Rerata skor pretest hasil belajar mahasiswa kelas eksperimen adalah 11,82 dan standar deviasi 5,86 demikian pula rerata skor pretest hasil belajar mahasiswa pada kelas kontrol adalah 11,61 dan standar deviasi 5,69.

Setelah diberi pembelajaran dengan model pembelajaran advance organizer berbasis peta konsep untuk kelas eksperimen dan konvensional untuk kelas kontrol, maka diperoleh skor postest untuk kemampuan representasi matematis pada kedua kelas. Rerata skor postest hasil belajar mahasiswa matematika pada mata kuliah struktur aljabar kelas eksperimen adalah 15,58 dan standar deviasi 5,27. Sedangkan rerata skor postest hasil belajar mahasiswa matemamatika pada mata kuliah struktur aljabar pada kelas kontrol adalah 12,45 dan simpangan baku 5,29.

Dari hasil rerata tersebut dapat dilihat bahwa terjadinya peningkatan hasil belajar mahasiswa matematika . Berdasarkan Uji hipotesis dengan menggunakan $\mathrm{Uji} \mathrm{t}$ diperoleh signifikansi $0,009<0,05$ sehingga $\mathrm{H}_{\mathrm{a}}$ diterima, yang menyatakan bahwa terdapat pengaruh model pembelajaran advance organizer menggunakan peta konsep terhadap hasil belajar mahasiswa matematika pada mata kuliah struktur aljabar daripada menerapakn pembelajaran konvensional. Pernyataan ini juga didukung dari hasil penelitian Suci Yuniati, (2013) dan Rezkiyana (2017) bahwa terdapat pengaruh model pembelajaran advance organizer terhadap hasil belajar mahasiswa matematika pada mata kuliah struktur aljabar. 
Vol III. No.2, Maret 2019, hlm. 117 - 124

Available online at www.jurnal.una.ac.id/indeks/jmp

\section{SIMPULAN}

Berdasarkan hasil analisis data, temuan dan pembahasan yang telah dikemukakan maka dapat diambil kesimpulan bahwa terdapat pengaruh model pembelajaran advance organizer terhadap hasil belajar mahasiswa matematika pada mata

\section{DAFTAR RUJUKKAN}

Abdurrahman,Mulyono.2003.Pendid ikan Bagi Anak Berkesulitan Belajar. Jakarta: Rineka Cipta Nurlaelah, elah. 2009. Pengembangan Bahan Ajar Struktur Aljabar yang Berbasis Program Komputer dan Tugas Resitasi untuk Meningkatkan Kreativitas dan Daya Matematik Mahasiswa. Bandung: Jurnal

Riduwan. 2006. Metode dan Teknik Menyusun Tesis. Bandung: Alfabeta. kuliah struktur aljabar. Hasil belajar mahasiswa matematika pada mata kuliah struktur aljabar dengan menerapkan model pembelajaran advance organizer lebih tinggi dari pada hasil belajar mahasiswa matematika dengan menerapkan pembelajaran konvensional

Yuniati, Suci. 2013. Peta Konsep (Mind Maping) Dalam Struktur Aljabar. Bandung: Jurnal Gamatika Vol. III No.2 Mei 2013

Sugiyono. 2010. Metode Penelitian Pendekatan Kuantitatif, kualitatif dan R\&D. Bandung: Alfabeta.

Zaini Hisyam dkk. 2008. Strategi Pembelajaran Aktif.

Yogyakarta: Pustak Insani Madani 